\title{
Application Research of Oral English Teaching of Situational Teaching with Multimedia Assistance
}

\author{
Fan Yang \\ Jiangxi Science \& Technology Normal University \\ JXSTNU \\ Nanchang, China \\ 771261123@qq.com \\ Xiaoqiang $\mathrm{Hu}$ \\ Jiangxi Science \& Technology Normal University \\ JXSTNU \\ Nanchang, China \\ 13870995168@163.com
}

\begin{abstract}
This paper has discussed the status quo in oral English teaching at colleges in China, and proposed that multimedia assistance is the related solutions, and demonstrated the advantages as well as how to use multimedia assistance technology in oral English instruction.
\end{abstract}

Keywords-College English ;multimedia technology; situational teaching; oral English instruction

\section{The STATUS QUO OF ORAL ENGLISH TEACHING IN COLLEGES.}

College English, compulsory and fundamental to college students, is an important part of higher education. Far different from high school English curriculum, college English pays more attention to students' ability in actual use, and as a instrumental language, training high-quality talents with specialized knowledge and capability of communicating in English fluently. The requirements of college English curriculum point out that the aim of college English teaching lies in cultivating students' comprehensive abilities in using English language, especially the speaking and listening skills, enabling them to conduct effective spoken and written communication in future work and social activities. Hence, it is undoubtedly that spoken English is of great importance. In recent years, many colleges have come to realize the importance of oral English and have carried out many reforms on English teaching, such as promoting hardware facilities and software development in multimedia teaching, gradually developing multimedia classrooms and network selflearning platforms. Besides, some schools even offer listening and speaking classes for non-English majors. However, their practice use of English in communication is still of low proficiency. The following factors, to a large extent, contribute to the negative effects in college oral English teaching.

\author{
Xuguang Min* \\ Jiangxi Science \& Technology Normal University \\ JXSTNU \\ Nanchang, China \\ * Corresponding Author: minxuguang@ vip.163.com \\ Lisheng Yuan \\ Jiangxi Science \& Technology Normal University \\ JXSTNU \\ Nanchang, China \\ yls10001@qq.com
}

\section{A. Learning Habits and Methods of English Learners}

In their study at university, many college students still maintain the learning habits and ways developed during high school period, featuring high scores, grammar and vocabulary memory, listening and reading skills as its core aim, ignoring spoken English because it has no direct impact on the test scores. They are unwilling to express and communicate in English in class because of their diffidence, not to mention conscientiously proceed special oral English training. This sort of unqualified habit for English study can't meet their needs of English learning at college.

\section{B. Backward Spoken English Teaching Methods of Teachers}

In class, teachers still use outmoded and traditional way of teaching--not well-prepared with the course and talking in general terms, even sometimes digressing from the topic. They make students learn by rote. In fact, conversely, the oral English class needs more elaborate preparation, correct guidance and active atmosphere, thus availing students with plenty of opportunities

\section{Intrinsic Characteristics of Spoken English}

Oral English learning, which is extensive and scattered in content, lacks logic and consistency; mechanical practicing and monotonous processing without obvious progress in a short time result in easily losing confidence and interest for students. The slow updated themes and contents offered by English textbooks are of no real help to communication. Errors incurred by cultural differences and language habits between English and native language, if not rectified in time, will pose negative impacts on their oral learning.

\section{Lack of Environment for Oral Practice}

The improvement of speaking ability requires practice. However, students are often exposed to Chinese language 
environment and are easily affected by their native language in pronunciation, intonation, sentence structure or way of thinking, which restricts the improvement of students' oral proficiency. At present, the main approach of English learning is classroom work, providing students with few opportunities to practice oral English after class.

\section{Situational Teaching With Assistance OF MUlTiMEdia TECHNOLOGY}

Foreign language class is an important place where teachers can cultivate students' competence of language communication. During the class, teachers organize students to participate in language communicative activities with all sorts of approaches to improve their oral proficiency. With the support of modern teaching technology, the situational teaching method carried out by multimedia has become an efficient way to enhance students' ability to speak English. The situational teaching has been implemented as early as 300 years ago when the famous Czech education expert Comenius once said "All knowledge begins with senses."[1]. Students seem to be personally on the scene as abstract knowledge is presented to them directly in perceptual vision. The situational teaching idea originates from the acquisition and proficient application of knowledge in real situations.

\section{E. Theoretical Basis of Situational Teaching Psychological Basis}

According to Treichler, an experimental psychologist, information gained through visual and auditory senses accounts for $94 \%$ of the total. That is, visual and auditory senses are the main accesses to information for human beings. He also points out that people's memory of reading materials lasts longest when it is formed by those two senses[2]. Multimedia efficiently integrates texts, sounds, images as well as animation together, stimulating students' perceptional senses. The stimulus-response mode, in terms of behaviourism psychology, is an important condition for language acquisition. With the help of multimedia technology, the real circumstance created by videos and sounds can render students' the ability to complete the progress from knowledge input through visual and auditory senses to the effective output under stimulus of certain circumstances.

\section{F. Basis of Cognitive Linguistics}

Oral English teaching is a process of creating appropriate circumstance for teachers and students to make verbal communication. From the point of cognitive linguistics, there is cognitive context in the process of verbal communication, which means the related knowledge one possesses on language application is actually a knowledge status that has been conceptualized or graphically presented. By setting up certain context, the original cognitive context is matched to the verbal context and new communication context is then created [3]. The dynamic context set by multimedia can produce the effect of real situation and compensate on the restriction of class as places for communication. For example, teachers can take advantages of the multimedia (slide, projection, broadcast, video, etc) in accordance with specific need of topics and communication to correspondingly construct the time, place, characters, backgrounds and so on so that students will be stimulated to grasp communicative language in a real and effective language context.

\section{AdVANTAgES OF Situational TEACHING}

In traditional oral English teaching, the target language is often separated apart and the approaches are mainly based on words and sentences teaching. That is because many teacher believe the students can make selective use of those simple sentences once they have grasped them. However, despite the great volume of words and sentences stored in their head, students are allowed with little time to memorize and select appropriate sentences in the real practice. Due to the lack of clear and specific context, students are not able to choose proper sentences to communicate in English fluently. While in comparison, situational teaching possesses lots of advantages in oral English Teaching.

\section{A. Establishment of Situation}

The situation establishment in teaching oral English is to establish a close-to-reality language environment in which all dialogues constitute a continuous integrity. Students are taught to select appropriate expressions promptly according to special circumstances, and finally blurt them out after repeated practice.

\section{B. Integration of Teaching Materials}

In situational teaching, materials are in an attempt to integrate into a scenario of continuous scenes. With the assistance of multimedia, teachers create a serial of interrelated situations with each progressing layer-by-layer. Those situations form connections in students' head so as to build new knowledge on the existing information and more complex schema on the original one.

\section{Improvement of Students' Interest}

Situational teaching can remarkably improve students' interest. The oral English teaching is carried out to an maximum extent in a vivid, lively and natural language environment so that students can be greatly stimulated. Besides, the multimedia assisted teaching method also combines the text with the whole, which can stimulate students' senses in an all- round way. Not merely the lessons are vividly presented, the chosen resources are also closest to the living present.

\section{Highlighting the Idea of Learner-centeredness}

The Traditional teacher-oriented teaching mode centers on the content while the multimedia assisted situational teaching emphasizes interaction between teachers and students. Students practice and innovate as much as possible in accordance with the situation established by their teachers, fully actualizing the idea of learnercenteredness.

\section{The APPLiCATION OF MULTimedia IN ORAL ENGLISH TEACHING}

\section{A. Discussion Topics Caused by Multimedia}

Compared with using textbook, blackboard and chalk in traditional teaching, the multimedia technology has prominent advantages in creating English teaching situation and guiding students to discuss. For example, in learning tourism, the teacher can show the Great Wall and 
the Yangtze River of China, the Pyramids of Egypt and other natural landscapes for the students to combine them with social, culture and other factors to discuss the advantages and disadvantages that tourism brings. This kind of discussion can not only simulate students' interest, but also create an active class atmosphere, so that students actively participate in the oral communication. Another example is that the teacher can guide students to describe the season. They can show students the pictures, sounds or videos about one season and place them in the scene of that season, and then describe its characteristics.

\section{B. Multimedia Provides the Background Knowledge}

Learning foreign language involves complicated social and cultural background. The context that teacher created should be matched with the implied cultural and social background of the theme and text. For instance, when students are talking about Halloween, the teacher can show some videos or items, such as mask, pumpkin lantern and so on; and can even decorate the classroom into a costume party, where students wear masks and fancy clothes dressed as ghosts to attend the ball. Only by matching the context and communicative context to each other can the class reach the best teaching effect. In another example of a virtual presidential campaign speech, hte teacher uses multimedia to play the speech video of the United States presidential campaign in recent years and then introduces the history and operation of the two party systems in United States. After that he divides the students into two party candidates and asks them to wear suits, co-play with the picture and sound effect, and do their best to create a real atmosphere of the presidential campaign.

The oral class under the multimedia aided teaching makes the students interested and creates many topics, which can not only do the combination of learning and using, but bring up the students' competence in correct and flexible use of English to communicate in different context[4-10].

\section{CONCLUSIONS}

Multimedia aided teaching is the trend of the oral English teaching as multimedia technology is becoming mature and perfect. It creates the favorable conditions and brings a series of reforms to the teaching method. Teachers need to create a situation that is in line with the students' needs in the vast information resources and a context of broad subjects. They should grasp the modern science and technology and carry out the interdisciplinary research between linguistics and information technology, explore a new teaching method that can meet the need of students and adapt the high tech teaching environment with continuous development.

\section{REFERENCES}

[1] Lixia Zhou. On Application of Situational Teaching Approach in Russsian Teaching[J]. Managment and Science \& Tech for SM Enterprises, 2014, (12).

[2] Jie Xiong. A Psychological Perspective of English Teaching with Multimedia[J].A Journal of University of Electronic Science \& Technology, 2001,(2).

[3] Dongchun Chen. A Perspective of Match of Situational Teching of English with Multimedia[J]. A Journal of University of Guangdong Foreign Studies,2010 (4).

[4] Ruiqin Song. On Oral English Teaching Mode with Multimedia Assistance[J]. Education of Tianjin,2006, (4).

[5] Zhi Yu.On College Oral English Teaching in Class with Multimedia Assistance[J].Test Weekly,2015, (2).

[6] L.Mason, P.Boscolo. Role of epistemological understanding and interestin interpreting a controversy an in topic-specific belief change[J]. ContemporaryEducational Psychology, 2004,29:103128.

[7] Xiaojuan Lv, Yue Yang. A study of topic based teaching application in elementary English education [J]. Journal of Xi'an International Studies University.2008,(3): 84-86.

[8] Lina Hao. The application of topic-based teaching in vocational English teaching $[\mathrm{J}]$. Higher education and academic research,2008,(8):149-151.

[9] Xiaotang Cheng. Analysis and design of English teaching materials[M].Beijing: Foreign language teaching and research press, 2008 .

[10] L. Cameron. Teaching languages to young learners [M]. Cambridge: Cambridge University Press,2001. 